Studia Judaica 21 (2018), nr 2 (42), s. 279-297

doi:10.4467/24500100STJ.18.013.10264

Anna Landau-Czajka

\title{
Kobiety w Palestynie oczyma polskojęzycznej prasy syjonistycznej
}

\author{
WOMEN IN PALESTINE IN THE EYES OF THE POLISH-LANGUAGE ZIONIST PRESS
}

\begin{abstract}
The Zionist ideology proclaimed the equality of men and women, according to which everyone, regardless of gender, should prepare oneself to go to Eretz Israel and work hard to create a future state. However, reality did not always correspond to ideology. In the Polish-language Zionist press, one can find texts from which it transpires that theoretical ideological assumptions were not always implemented in practice. Despite the officially proclaimed gender equality, women were typically assigned to feminine activities, while being removed from more responsible ones. Neither did they themselves always wish to change the traditional division of roles. In the 1930s, this problem began to be noticed and inspired reflections on the possibility of changes.
\end{abstract}

Keywords: Palestine, women, kibbutz, gender equality.

Słowa kluczowe: Palestyna, kobiety, kibuce, równouprawnienie.

Niniejszy artykuł o kobietach w Palestynie w okresie międzywojennym, oparty na polskojęzycznej prasie syjonistycznej ${ }^{1}$, dotyczy wizerunku tych kobiet, ich roli w Erec Israel, nie zaś realnej rzeczywistości palestyńskiej,

${ }^{1}$ Wykorzystane zostały artykuły z następujących czasopism: „Diwrej Akiba” 1936 - pismo Gdudu, pierwszego ruchu Ha-Noar ha-Iwri „Akiba”; „Dzienniczek dla Dzieci i Młodzieży” (dodatek do „Nowego Dziennika”) 1925-1939; „Ewa” 1928-1930; „Filary. Miesięcznik Akademicki” 1939; „Mały Przegląd” (Dodatek dla dzieci i młodzieży do „Naszego Przeglądu”) 1926-1939; „Młody Czyn. Pismo Młodzieży Szomrowej” 1938; „Nasz Przegląd” 1923-1939; „Nasze Hasła” 1928; „Nowe Tory. Organ Polskiej Federacji W.I.Z.O.” 1935; „Przegląd Palestyński” 1935; „Tygodnik Żydowski” 1919-1920. 
która - sądząc z niektórych relacji prasowych - była bardzo odległa od tego, co o niej pisano. Wykorzystanie prasy syjonistycznej wyłącznie w języku polskim może dać w miarę pełny obraz zagadnienia, ponieważ w międzywojniu ukazywało się wiele tytułów reprezentujących różne orientacje polityczne i przeznaczonych dla różnorodnych odbiorców. Prasa ta, mimo istnienia jednocześnie prasy jidyszowej, cieszyła się dużą popularnością, a dzienniki, takie jak „Nasz Przegląd” (formalnie niezwiązany z żadną partią, ale o sympatiach syjonistycznych) czy „Chwila”, były zdecydowanie opiniotwórcze. Oczywiście istniała też syjonistyczna prasa w języku jidysz, jak choćby bardzo popularny warszawski dziennik „Hajnt”.

Zostały tu wykorzystane przede wszystkim artykuły z młodzieżowej prasy syjonistycznej, ponieważ propaganda syjonistyczna zwracała się do ludzi młodych, silnych, którzy mieli chęć i możliwości rozpoczęcia zupełnie nowego życia w Erec. Ludzi starszych czasem wręcz zniechęcano do wyjazdu. Tytułów takiej prasy było znacznie więcej, niż zostało tu przywołanych, ale w wielu nie wspomina się w ogóle o kobietach w Palestynie. Oprócz pism młodzieżowych uwzględniono tylko „Ewę” - jedyne czasopismo żydowskie dla kobiet, przede wszystkim z klasy średniej, redagowane przez Paulinę Appenszlakową. Nie miało ono ściśle syjonistycznego nastawienia, ale redaktorka pisma sympatyzowała $\mathrm{z}$ tą ideologią - podobnie jak jej mąż, redaktor naczelny „Naszego Przeglądu”. Wreszcie „Mały Przegląd”, dodatek dla dzieci i młodzieży do „Naszego Przeglądu”, składający się z listów i tekstów swoich młodych czytelników, stanowi tu pewną przeciwwagę dla ideologicznych artykułów z innych pism.

Celem artykułu nie jest opisanie życia kobiet w Palestynie czy działalności kobiet $w$ ruchu syjonistycznym ${ }^{2}$, lecz przyjrzenie się pewnym mechanizmom propagandowym, które były bardzo widoczne tam, gdzie pisano o ideologii, ale częściowo lub całkowicie nieobecne w osobistych relacjach z kibuców, zebrań czy wreszcie - z życia w Palestynie. Propagowana równość kobiet i mężczyzn przedstawiana jako cel już zrealizowany okazywała się iluzją tam, gdzie opisywano rzeczywistość3.

${ }^{2}$ Na ten temat zob.: Katarzyna Czerwonogóra, Syjonistyczny ruch kobiet w Europie na przełomie XIX i XX wieku, „Studia Judaica” 18 (2015), nr 2, s. 271-291.

${ }^{3}$ Badania prowadzone nad podziałem pracy w kibucach opisane są m.in. w: Lionel Tiger, Joseph Shepher, Women in the Kibbutz, New York-London 1975. 


\section{Przygotowanie do wyjazdu}

Zanim przejdę do opisów życia kobiet w Erec, zacznę od podstaw, czyli od założeń syjonistycznych organizacji młodzieżowych przygotowujących Żydów do wyjazdu do Palestyny, czyli do alii. Jedną z najwcześniej powstałych i najliczniejszych organizacji był lewicowy Ha-Szomer ha-Cair. Oprócz tego lewicę reprezentowały: Gordonia (choć działała głównie w Palestynie), He-Chaluc, do której należał słynny kibuc na Grochowie, oraz kilka innych organizacji. Najbardziej prężny był chyba Ha-Szomer ha-Cair, który próbował stworzyć „nowy typ Żyda”, wychowując dzieci i młodzież według wzorców ruchu skautowego. Zamiast młodzieńca zagłębiającego się w świętych księgach i kiwającego się nad Talmudem oraz kobiety prowadzącej koszerny dom i wychowującej dzieci organizacje te pragnęły widzieć młodych ludzi wysportowanych, zdrowych, nadających się do ciężkiej pracy fizycznej na roli i w fabrykach Erec. Mieli pracować razem, w tych samych miejscach, robić to samo, prowadzić wspólne życie w kibucach - co całkowicie zaprzeczało tradycyjnemu podziałowi ról w rodzinach żydowskich i budziło niepokój wielu ortodoksyjnych rodziców.

Ważnym elementem ideologii było więc zrównanie praw dziewcząt i chłopców. Nie powstał wobec tego oddzielny wizerunek idealnego szomra i idealnej szomeret, którym przypisywano by odmienne zalety i różne zadania w nowym kraju. Przeciwnie: wielokrotnie podkreślano, że wszyscy członkowie organizacji mają być odważni, sprawni, samodzielni; wszyscy mają uczestniczyć w wycieczkach, jeździć na obozy, stać na warcie i brać udział w zajęciach paramilitarnych. Dobierano odpowiednie lektury na zbiórki, aby przekonać o tym dziewczęta ${ }^{4}$. Później, w Palestynie, zarówno dziewczęta, jak i chłopcy będą przecież prowadzić proste życie kibucników, wypełnione pracą fizyczną, zrównujące obowiązki i prawa obu płci.

Ten ideał jednak nie sprawdzał się w zderzeniu z rzeczywistością, i to już na etapie przygotowań. Tam, gdzie mamy relację nie z kolonii szomrowych czy zbiórek, po których młodzi ludzie wracali do rodzinnego domu, lecz z kibuców na terenie Polski przygotowujących młodzież do pracy w Erec, okazuje się jednak, że zupełnie czego innego oczekiwano od chłopców, czego innego zaś od dziewcząt. W kibucach zamieszkałych przez młodzież wychowaną w międzywojennej Polsce, często w konserwatywnych i tradycyjnych sztetlach, młodzi ludzie w sposób automatyczny - i nierzadko chyba bezrefleksyjny - powielali wzorce znanego im świata, który w codziennym

${ }^{4}$ Anka, 53 zbiórki szomrowe, „Mały Przegląd” (31 października 1930), nr 300, s. 2. 
gospodarowaniu, pracy i życiu domowym przeznaczał każdej z płci inne role. Jeden z członków takiego kibucu, Chaim, pisał wprawdzie, że nie ma u nich podziału na dziewczęta i chłopców, tylko na silnych i słabych ${ }^{5}$, ale fakt, że do zarządu wybrano ośmiu chłopców i jedną dziewczynę, pozostawił bez komentarza, nie dostrzegając żadnej sprzeczności w swoim opisie ${ }^{6}$. We wspomnieniach dziewczyny, uczestniczki kibucu, pojawia się informacja, że na dwudziestu chłopaków w tarnopolskim kibucu były cztery dziewczęta. Oczywiście pewna selekcja przebiegała jeszcze wcześniej - przygodę, przygotowanie do emigracji i ciężką pracę wybierali raczej chłopcy. Widać to było zresztą w samym Erec, gdzie brakowało dziewcząt.

Trudno ocenić, jak wyglądała praca dziewcząt w kibucach. Ze wspomnień wyżej wymienionego Chaima wynika, że kierowano je raczej do kuchni, one same jednak często chciały uczestniczyć w „poważniejszych” pracach. Inny, młodszy korespondent, opisując kibuc, który zwiedzał, pisał: „Jedni pracują w fabryce, inni chodzą rżnąć drzewo. Dziewczęta gotują, sprzątają, piorą i szyją. Niektóre także chodzą do fabryki"7. Kucharkami w kibucach były głównie dziewczęta. W kibucu w Chrzanowie chyba nieprzypadkowo kuchnia była jednocześnie sypialnią dziewcząt, chłopcy zaś mieli oddzielny pokój, który służył im jedynie jako sypialnia. Ulokowanie chalucek nie było przypadkowe, one bowiem gotowały proste obiady, podczas gdy chłopcy pracowali na zewnątrz ${ }^{8}$. Podobnie w pokazowym kibucu na Grochowie - pralnia była wspólna, ale bieliznę prały tam chalucki, gdy mężczyźni w tym czasie pracowali w polu i fabrykach. Nie jest jasne, czy pranie było ich jedynym zajęciem, czy też prały dodatkowo - po pracy. Faktem jest jednak, że uznano to za zajęcie kobiece ${ }^{9}$. Natomiast nie ma co do podziału pracy żadnych wątpliwości w innym kibucu - w Kielcach. Tam wprawdzie proporcje płci były niemal równe (70 mężczyzn i 60 kobiet), ale chaluce pracowali w warsztatach, przy budowach domów, w tartakach, a chalucki jako posługaczki i kucharki. W dodatku zwiedzający kibuc reporter nie zobaczył kuchni, a było to jedyne pomieszczenie, do którego nie wszedł, choć miał ochotę, lecz przewodniczka zapomniała o tym miejscu, on zaś wstydził się przyznać, że interesuje się „garnkami”"

5 Chaim, Ze wspomnień chaluca, „Mały Przegląd” (19 czerwca 1931), nr 167, s. 2.

${ }^{6}$ Listy Chaima z kibucu (dokończenie), „Mały Przegląd” (1 kwietnia 1931), nr 90, s. 2.

${ }^{7}$ Co u nas stychać. Emil z Siemiatycz. Praca w kibucu, "Mały Przegląd” (20 stycznia 1933), nr 20, s. 4.

8 Izaris, Hachszara w Chrzanowie, „Mały Przegląd” (27 lipca 1934), nr 213, s. 6.

9 Moniek L., Ferma chaluców na Grochowie, „Mały Przegląd” (28 października 1937), nr 307, s. 2.

${ }^{10}$ Welwek z Kielc, W kieleckim kibucu, „Mały Przegląd” (16 grudnia 1938), nr 351, s. 3. 


\section{W Palestynie}

Jak widać, chociaż ideologia nie przewidywała podziału obowiązków na męskie i kobiece, rzeczywistość była zupełnie inna. Jak się wydaje, podobnie sprawa wyglądała w Palestynie. Ten bardzo typowy podział pracy potwierdzał też reportaż drukowany w innym młodzieżowym piśmie, „Dzienniczku dla Dzieci i Młodzieży”, dodatku do krakowskiego, syjonistycznego „Dziennika Nowego”. Żartobliwy opis poranka w palestyńskim kibucu jest jednocześnie bardzo dobrym obrazem wykonywania obowiązków i zachowania obu płci. „Wstawanie o 3 rano było normą, ale i przygodą. Dójki, pielęgniarki, kucharki wstawały bez problemu, chłopcy w kibucu nieco się ociągali. Jeden próbował się wykręcić od wstawania chorobą. Inny rzucał w dyżurnego butem"11. Innymi słowy, dziewczęta nie tylko kierowane były do typowo kobiecych czynności, ale w dodatku stereotypowo odgrywały role sumiennych i porządnych, podczas gdy młodzi mężczyźni mieli prawo do ociągania się i migania się od obowiązków. Skutkiem rozbieżności między ideologią a rzeczywistością było wiele różnych narracji, nieprzystających do siebie i ukazujących zupełnie sprzeczne ze sobą wizje roli kobiet.

Zacznijmy od tego, co rzuca się w oczy, gdy szuka się jakichkolwiek wiadomości o kobietach żydowskich w Erec. Jest to brak informacjizazwyczaj całkowicie pomijano ten temat. Syjonistyczne czasopisma poświęcone życiu w Palestynie często w ogóle nie wspominają, że są w niej jakieś kobiety ${ }^{12}$ - na pierwszy plan wysuwają się mężczyźni: pracujący w kibucach, fabrykach czy walczący z Arabami. Jeśli podaje się statystyki napływu ludności do konkretnych kibuców czy imigracji chaluców do Palestyny, to płeć jako kategoria właściwie nie występuje, a teksty pisane są jedynie w rodzaju męskim ${ }^{13}$. Kobiety są pomijane, gdy trwają dyskusje nad kształtem syjonizmu czy nad tym, jak zapewnić pracę przyjeżdżającym, kto w Palestynie jest potrzebny. Praktycznie mowa jest tylko o mężczyznach, męskich zawodach i wypowiadają się jedynie mężczyźni, zwłaszcza w najwcześniejszym okresie. W „Tygodniku Żydowskim” z lat 1919-1920

${ }^{11}$ Wstawać! Opowiadanie z życia najmłodszych chaluców, „Dzienniczek dla Dzieci i Młodzieży” (14 maja 1937), nr 132, s. 10.

${ }_{12}$ Na przykład pismo młodzieży z Poalej Syjon, „Nasze Hasła”, było żywo zainteresowane położeniem proletariatu w Palestynie, ale wydaje się, że cały ten proletariat był wyłącznie płci męskiej - zob. Proletariat żydowski a palestynizm, „Nasze Hasła” (lipiec-sierpień 1928), nr 3-4, s. 15-20.

${ }_{13}$ Zob. np. Kibuc w Palestynie, „Diwrej Akiba” (26 czerwca 1936), s. 299. 
kobiety nie istnieją ani jako przyszłe osadniczki, ani jako dyskutantki, ani jako osoby, do których się zwracano, aby wspomogły Erec - jest mowa tylko o Żydach, mężnych chalucach, dzielnych szomrach, natomiast słowo Żydówka w odezwach się nie pojawia. Tymczasem syjonistyczne organizacje kobiece istniały, sporadycznie czasopismo wymieniało je nawet $\mathrm{z}$ okazji relacji ze zjazdów (np. Stowarzyszenie Kobiet Syjońskich „Hadassa”), ale głosu im nie udzielano ${ }^{14}$.

Artykuły na ten temat (poza „Ewą”) są rzadkie, tak rzadkie, że można czasem przejrzeć całe roczniki syjonistycznego pisma i nie natrafić na informację, że kobiety w Palestynie istnieją. Jeśli pojawiają się czasem, to nie w artykułach problemowych, ale w dziale listów z Palestyny.

Gdy jednak przeanalizujemy nieliczne artykuły dotyczące spraw kobiet, to mamy do czynienia z kilkoma zupełnie odrębnymi narracjami. Pierwsza - to ukazywanie ideału kobiety chalucki jako rzeczywistości. Kobiety w Erec miały przede wszystkim porzucić swoje poprzednie życie, być robotnicami lub mieszkać w kibucu, nie opuszczać go niezależnie od sytuacji czy dramatycznych wydarzeń - jeśli jej męża zabili Arabowie, to prawdziwa chalucka znajdowała sobie następnego i nie opuszczała kibucu. Idealnym przykładem takiego artykułu jest tekst z „Filarów” pt. Kobiety Galilei. Sztandarową postacią jest tu Rachel Blaustein, poetka, rosyjska intelektualistka, która w Erec pracowała jako prosta robotnica. Ale w artykule opisywane są też kobiety, które straciły mężów, lecz mimo to nadal trwały przy zasadach chalucowych - wychodziły w pole z biczem, aby odganiać Beduinów, nieprzywykłych do widoku kobiet przy pracach polowych. Ciężarne kobiety pracowały w kuchni. Intelektualistki, absolwentki studiów kaleczyły sobie dłonie o drut kolczasty albo tłukły kamienie na szosie. Wychowane już w kibucach młode dziewczęta nosiły „piętno tej ziemi - spokój i dzielność, zaufanie do losu i równowagę umysłu, której nie tracą nigdy, nawet w obliczu najcięższych przejść" ${ }^{15}$. Kobieta idealna była robotnicą w kibucu, rzadziej - obrończynią ziemi, którą zamieszkiwała. W tę narrację wpisują się na przykład listy publikowane w „Diwrej Akiba”. Dziewczęta opisywały swoje prace, typowo męskie. Ryfka pracuje przy łupaniu kamieni i znajduje w tym zajęciu „zupełne zadowolenie”"16. Rola żony i matki została zmarginalizowana, stała się nieistotna, z jednym

${ }^{14}$ Z ruchu hebrajskiego [rubryka: Kronika żydowska], „Tygodnik Żydowski” (30 kwietnia 1920), nr 18, s. 8.

${ }^{15}$ L. Jaffe, Kobiety Galilei, „Filary” (20 kwietnia - 15 maja 1939), s. 2.

16 Ryfka, Listy palestyńskie, „Diwrej Akiba” (20 listopada 1936), nr 6, s. 135. 
wyjątkiem - zadaniem kobiety było wychować dzieci na kibucników, którzy nie opuszczą swojej społeczności, chyba że w celu przejścia do innego kibucu, na inny posterunek.

Warto wspomnieć tu także o jeszcze jednej istotnej sprawie. Wbrew stereotypowi oczekiwano od dziewcząt, że zawsze wybiorą pracę dla kraju ojczystego - Erec, a nie obowiązek opieki nad starymi rodzicami. O ile takie oczekiwanie było dosyć powszechne wobec mężczyzn, o tyle w wypadku kobiet wymagało przełamania pewnego tabu, wytłumaczenia, że rodziców, nawet potrzebujących opieki, wolno zostawić samych - córka nie musi brać ich (ani swoich) uczuć pod uwagę. W skierowanych do młodzieży syjonistycznej pismach wyjazd do Erec był rzeczą tak pożądaną, tak cenioną, iż wyjeżdżający w ogóle nie przejmowali się tym, że zostawiają rodziców i dziadków (o innych wypadkach raczej nie pisano). Członkowie rodzin, którzy zostawali w kraju, wprawdzie wiedzieli, że będą tęsknić, ale bez wątpienia cieszyli się możliwościami, jakie otwierały się przed ich dziećmi w Erec. W skierowanym do małych dzieci czasopiśmie „Okienko na Świat” wręcz piętnowano tych, którzy tęsknią za rodziną. „Niedołęgi i ciury mogą zostać w golusie, bo by płakały w drodze: My chcemy do mamusi! Nowe, silne państwo wymaga poświęcenia i o tym powinny wiedzieć dzieci, że dla szczęścia nowej ojczyzny i własnego należy porzucić nawet rodzinę"17. Bardzo ciekawy jest też stosunek do rodziców. W „Dzienniczku dla Dzieci i Młodzieży" można zauważyć takie konstatacje, że wobec pozostawionej w kraju rodziny nie obowiązuje żadna lojalność. Moralna konieczność wyjazdu do Erec była ważniejsza niż obowiązek opieki nad rodziną. Aby zrozumieć, jak bardzo zideologizowany był syjonistyczny przekaz oficjalny w porównaniu z tym, co pisały same dzieci, warto przyjrzeć się kwestii rozłąki z rodziną w „Małym Przeglądzie”, w którym opisywano własne przeżycia, nie przejmując się ideologią oficjalną. Tu przekaz był bez porównania bardziej tradycyjny. Młodzi ludzie, nawet emigrujący do Erec, utrzymywali kontakt z rodziną, a przede wszystkim - co jest istotne - tęsknili za nią, konieczność jej porzucenia uznawali za bardzo dotkliwą stratę. Dziewczyna relacjonująca swoją drogę do Palestyny pisze:

Myślałam ciągle [...] o moich kochanych, najdroższych rodzicach. Widziałam ciągle mamusię na dworcu, tatusia z braciszkiem, biegnących za pociągiem, wołających mnie i płaczącą siostrzyczkę [...] Naprawdę, gdybyśmy tu byli wszyscy razem, byłabym najszczęśliwszą istotą na świecie, bo jednak uczucie rodzinne góruje nad

${ }_{17}$ Monika Szabłowska-Zaremba, „Okienko na Świat. Pismo dzieci i młodzieży” 19371939, „Annales Universitatis Paedagogicae Cracoviensis” 13 (2015), s. 200. 
umiłowaniem idei. Mam nadzieję, że wkrótce moi bliscy przyjadą i tylko ta nadzieja krzepi mnie, dodaje otuchy i siły do pracy ${ }^{18}$.

Radość z wyjazdu mieszała się więc ze smutkiem, nie była zatem jednoznaczna.

Kobiety ograniczające kontakty z rodziną, wychowujące dzieci, które mogły zginąć, czekające na mężów, niepozwalające sobie na uczucia tęsknoty, smutku czy rozpaczy - to tworzenie mitu, wzorca, w zasadzie kopii matki Polki; praca dla narodu, dla państwa była bowiem zawsze ważniejsza od rodziny i uczuć. Kobiety i mężczyźni byli tu teoretycznie równi, choć kobiety były raczej tymi, które czekają, a mężczyźni tymi - którzy giną.

Drugi nurt narracji pojawiał się rzadko i pokazywał nie tyle problem kobiet, ile problemy z kobietami. Przy czym wydaje się, że musiano o tym raczej mówić niż pisać bądź że takie opinie pojawiały się w pismach jidyszowych, ponieważ artykułów o tym, iż Żydówki wyjeżdżające do Palestyny nie wywiązują się ze swoich obowiązków, wolą wygody miasta niż kibuce, w prasie polskojęzycznej właściwie nie ma. O tym, że podobne opinie musiały być jednak dosyć rozpowszechnione, świadczą liczne polemiki. „Nasz Przegląd”, zainteresowany kwestiami kobiecymi, pisał stosunkowo dużo o roli kobiet żydowskich w Palestynie i właśnie publicyści tej gazety podkreślali, że chalucki są niedoceniane. Publicyści tego czasopisma oburzali się, że o mężczyznach w Palestynie pisano nieustannie, przedstawiano ich jako rycerzy, śpiewano o nich pieśni, a rolę kobiet pomijano, więcej nawet: jeśli już o nich mówiono i pisano, to wyłącznie w tonie krytycznym. Tymczasem kobiety w Palestynie, jak twierdził „Nasz Przegląd”, ponoszą wiele ofiar dla swojego kraju, muszą porzucić rodzinę, nie zawsze mają dość siły do tak ciężkiej pracy, jaka na nie czeka. Problemem, który należałoby rozwiązać, był brak fachowego przygotowania chalucek - dyplom uniwersytetu nie wystarczył do prowadzenia gospodarstwa rolnego w trudnych warunkach. W artykule streszczano broszurę Kobiecej Międzynarodowej Organizacji Syjonistycznej, jaka ukazała się na ten temat ${ }^{19}$.

„Nasz Przegląd”, czasopismo przeznaczone dla warstw mieszczańskich i inteligencji, zajmował się przede wszystkim obroną inteligentek żydowskich, które po przyjeździe do Erec Israel nie wybrały życia w kibucach, ale zamieszkały w miastach. Wbrew panującym stereotypom nie były to, jak podkreślali publicyści, osoby leniwe, niezdolne do poświęceń - przeciwnie,

18 Jocheweth z Tel-Awiwu, Do Palestyny, „Mały Przegląd” (7 sierpnia 1936), nr 230, s. 1.

19 P. A., Chalucka, „Nasz Przegląd” (25 marca 1927), nr 86, s. 3. 
te kobiety musiały zrezygnować z bardzo wielu rzeczy, a pracowały równie ciężko, jak ich towarzyszki na wsi. Streszczając dyskusję na ich temat z hebrajskiego pisma „Ha-Isza”, „Nasz Przegląd” stanął po stronie tych dyskutantów, którzy podkreślali, że nie tylko praca na roli jest zajęciem szlachetnym, kobiety z miasta bowiem także poświęcają wiele, aby móc pomagać w wielkiej narodowej i społecznej pracy, jaka jest do wykonania w Palestynie ${ }^{20}$.

Wreszcie trzeci rodzaj artykułów dotyczył nie ideologii, lecz realnego życia kobiet w Erec. W tym wypadku wizja nie była już tak idealna. Zastanawiające jest jednak to, że chociaż „poważne” czasopisma czasem pisały o ciężkiej doli kobiet w Palestynie, a nawet więcej - o ich nierównouprawnieniu i dyskryminacji, jednak zawsze stosowały czas przeszły - zjawisko to uznawały za symptomatyczne dla początków osadnictwa w Erec, ale obecnie już nieistniejące, przezwyciężone. Ada Fiszman, działaczka robotnicza, przyznawała, że w latach 1904-1905:

[kobiety] przybywały samotne, pojedyncze. Koloniści niechętnie spoglądali na robotnika-Żyda, garnącego się do pracy wiejskiej, cóż dopiero na dziewczęta! Nazywano je „biełoruczki”, nikt nie wierzył w ich siły i zdolności do pracy wiejskiej. Przedostawały się do kolonii najprzód więc jako krawczynie i szwaczki. Dziewczęta, które wchodziły do kibuców i kwuc, także mierzone były pogardliwym spojrzeniem. Powierzano im pracę wyłącznie w kuchni. To upokarzające stanowisko, świadomość, że znów się jest niezdatnym do niczego prócz kuchni, ciążła sumieniu chalucath, które przybyły, by uczestniczyć wraz z chalucem w odbudowie Erec Izrael ${ }^{21}$.

Zdaniem Ady Fiszman współcześnie (czyli pod koniec lat dwudziestych) sytuacja była już inna, pojawiły się wykwalifikowane kadry kobiece, kibuce kobiece, wszystko się zmieniło na lepsze.

\section{Równouprawnienie? Niekoniecznie...}

Cennym źródłem informacji okazuje się „Mały Przegląd”, do którego pisały dzieci i młodzież, a nie zawodowi publicyści, dzieci bowiem opisywały swoje palestyńskie życie nie zgodnie z wzorcem, lecz tak, jak je widziały. Będąca podstawą kibucowej ideologii wspólna praca dziewcząt i chłopców, przemiana, którą opisywała Ada Fiszman, jakoś nie znalazła

${ }^{20}$ T.zw. inteligentna kobieta w Palestynie, „Nasz Przegląd” (26 września 1927), nr 266, s. 6.

${ }^{21}$ Mirjam Wolman-Sieraczkowa, Robotnica żydowska (Rozmowa „Ewy” z p. Ada Fiszman - przywódczynią robotnic w Palestynie), „Ewa” (10 czerwca 1928), s. 2. 
odzwierciedlenia w reportażach Harry'ego Kaliszera, reportera i jednego z najbliższych współpracowników „Małego Przeglądu”. Po paru miesiącach pobytu w Palestynie stwierdzał on, że podział pracy niczym się tam nie różni od podziału pracy w Europie. Pisał m.in.:

Najlepiej zarabiają dziewczęta, które umieją dobrze gotować. Znam wiele wykształconych dziewczyn, które zarobkują jako kucharki, kelnerki lub pokojówki. Radzę więc nauczyć się przede wszystkim dobrze gotować. W Tel Awiwie prawie wszyscy jadają w restauracjach, bo jest dużo młodzieży samotnej, która nie prowadzi gospodarstwa ${ }^{22}$.

Chyba należy wierzyć Harry'emu, bo jego spostrzeżenia zgadzają się z tym, co było widoczne w kibucach polskich. Innymi słowy, wizja, że dziewczęta wyjeżdżają do Erec tylko ideowo, do kibuców, nigdy zaś po to, aby zarobić czy wręcz znaleźć sobie męża (o czym będzie mowa dalej), najwyraźniej była tylko mitem.

Zupełnie sporadycznie, na marginesie i bez wyjaśnienia, problemy z pracą kobiet $w$ kibucach pojawiają się także w listach do redakcji: „Dotychczas wszyscy pracowaliśmy, ale ostatnio utraciliśmy prawie że wszystkie placówki dziewcząt" ${ }^{\prime 23}$.

W dodatku, o czym prawie nie pisano w czasopismach syjonistycznych, wcale niełatwo było znaleźć pracę w kibucu czy w fabryce, bezrobocie było duże i często uderzało przede wszystkim w kobiety, poszukiwano bowiem raczej silnych mężczyzn do prac fizycznych. Palestyńska organizacja WIZO (Women's International Zionist Organization) ${ }^{24}$ otworzyła nawet poradnie zawodowe dla swoich członkiń, aby łatwiej mogły się odnaleźć na trudnym rynku pracy ${ }^{25}$. Dowodzi tego także powstanie organizacji kobiecych chroniących kobiety przed trudnościami, jakie napotkały, usiłując podjąć pracę w Palestynie:

Robotnice w Erec stanowią 50\% Histadruth Haowdim [Narodowy Związek Pracowników]. Specyficzne trudności, które napotykały dziewczęta na swojej drodze w dziedzinie pracy, fachu, płacy, stosunku pracodawców do „córy Izraela” itp., wywołały potrzebę specjalnej organizacji robotnic. Każde miasto, każda wieś ma swoją radę robotnic, które intensywnie pracują nad zdobyciem nowych placówek pracy w rolnictwie i przemyśle. Prowadzą też pracę kulturalną i społeczną ${ }^{26}$.

${ }^{22}$ Harry w Palestynie, „Mały Przegląd” (2 marca 1934), nr 61, s. 3.

${ }_{23}$ S. Gruner, Listy palestyńskie, „Diwrej Akiba” (20 listopada 1936), nr 6, s. 135.

${ }^{24}$ Powstała w 1920 r. kobieca organizacja syjonistyczna, w Polsce działała od roku 1925.

${ }_{25}$ Z rubryki Kronika palestyńska, „Nowe Tory” (grudzień 1935), nr 1, s. 13.

${ }^{26}$ W Erec. Posiedzenie Rady Robotnic, „Młody Czyn” (marzec 1938), nr 2, s. 16. 
Poświęcone Palestynie pisma syjonistyczne całą uwagę skupiały na pracy w kibucach, pomijając właściwie wszystkie inne kierunki aktywności Żydów na tym obszarze. Ze stosunkowo nielicznych artykułów można wywnioskować, że idealny wizerunek współpracy obu płci w kibucach musiał jednak być właśnie tym - idealnym wizerunkiem, nie zaś codzienną rzeczywistością. Inaczej bowiem nie byłoby potrzeby tworzenia kibuców kobiecych, które podobno cieszyły się popularnością i miały być dla przybywających do Palestyny dziewcząt swoistą szkołą, przygotowaniem do życia i pracy w Erec. Jak twierdzi autor artykułu, gospodarstwa te niemal całkowicie obywały się bez pracy męskiej - kobiety orzą, nawożą, okopują i nawadniają pardesy [sady]. Mężczyzn proszono o pomoc tylko wtedy, gdy do wykonania pracy potrzebna była szczególna siła fizyczna. I dodawał: „Można sobie wyobrazić, jak są z tego dumne”27. Na pewno były, bo w innym czasopiśmie znajduje się tego potwierdzenie w liście chalucek skierowanym do redakcji:

Zaobserwowałyśmy przypadkowo rzecz bardzo ważną w naszym meszeku [farmie]. Dotychczas miałyśmy kilkunastu płatnych robotników, teraz mamy ich o wiele mniej, ponieważ okazało się, że również dziewczęta są zdolne tę samą pracę wykonywać. W mniejszych meszekach [...] jest tylko jeden robotnik. A zatem dziewczęta mogą w dużej mierze dać sobie same radę $^{28}$.

Jednak dalsza część artykułu - a także pewne fragmenty listów świadczą o tym, że sprawa nie była taka prosta. Gdy wczytamy się w treść artykułu o samodzielnych kobiecych gospodarstwach rolnych, dowiemy się, że jednak kształcenie do tradycyjnych ról kobiecych wygrywało nawet w kibucach kobiecych. Okazuje się, że ich głównym celem nie było przygotowanie do pracy na roli, lecz do prowadzenia domu na wsi - co dla większości Żydówek było zupełnie nowym doświadczeniem: „wielka część kobiet zajmuje się głównie, jeśli nie wyłącznie, gospodarstwem domowym, należy im zatem dać właściwe przygotowanie i umożliwić postawienie tego działu na odpowiednim poziomie"29. Czyli gospodarstwa „bez mężczyzn”, a przynajmniej niektóre z nich, kształciły dziewczęta nie na samodzielne robotnice, ale raczej na gospodynie domowe. A więc te dziewczyny, całkowicie zrywające z tradycją, zostawały bardzo szybko - choć w sposób niekonwencjonalny - wdrażane do typowo tradycyjnych zajęć. W dodatku

${ }^{27}$ Michał Neugoldberg, Gospodarstwo kobiece. Bez mężczyzn, „Przegląd Palestyński” (21 kwietnia 1935), nr 1, s. 11.

${ }^{28}$ List chalucek, ,Nowe Tory” (luty-marzec 1936), nr 2, s. 5.

29 Neugoldberg, Gospodarstwo kobiece..., s. 11. 
wydaje się, że choć propaganda przekonywała kobiety, iż bez problemu znajdą pracę w tego typu kibucach, wcale nie było to takie proste. Zmartwione chalucki skarżyły się, że gdy zakończyły pracę w kibucu żeńskim, nie bardzo mają co dalej ze sobą zrobić. Przybyły do Erec, aby nauczyć się pracy na roli, tymczasem na przeszkodzie stoi polityka: one, jako apolityczne działaczki WIZO, nie chciały iść do pracy w gospodarstwach innych organizacji, a WIZO własnych kibuców nie ma ${ }^{30}$. Mężczyźni takich problemów nie sygnalizowali - mieli do wyboru znacznie więcej miejsc pracy ${ }^{31}$.

W polskojęzycznej prasie syjonistycznej nie pojawia się też motywacja, którą podaje w swoim artykule o kobietach w kibucach Lilach Rosenberg-Friedman:

Niektóre kobiety przyłączyły się do kibucu ze względów społecznych; bliska grupa często była substytutem rodziny, którą pozostawili, a także jej styl życia był najlepiej dostosowany do warunków panujących w Erez Israel. Ponadto niektórzy członkowie uważali, że kibucowy styl życia zmieni ich status, ponieważ grupa będzie w stanie zapewnić im więcej możliwości rozwoju osobistego ${ }^{32}$.

Wybór życia w kibucu miał - według publicystów prasy polskojęzycznej - zawsze podłoże ideowe, pomijano więc wszelkiego typu pragmatyczne przesłanki, które skłaniały kobiety do zamieszkania właśnie w nich. Starano się też nie przypominać o potencjalnej samotności kobiet, które zostawiały w kraju całą swoją rodzinę.

\section{Nie tylko kibuce}

„Ewa”, żydowskie czasopismo dla kobiet, blisko powiązane z „Naszym Przeglądem" (jego redaktorem naczelnym była Paulina Appenszlakowa), to jedyny periodyk usiłujący pokazać całokształt życia kobiet w Palestynie. Dobitnie - i na pewno nieprzypadkowo - podkreślano, jak ważne są kobiety w miastach, a nie tylko mieszkanki kibuców. Prócz artykułów o robotnicach

30 List chalucek...

31 Ze statystyk podanych przez „Przegląd Palestyński”, dotyczących zatrudnienia członkiń Histadrutu, wynikało, że w praktyce do kibuców trafiało bardzo niewiele kobiet, a większość tradycyjnie zajmowała się domem. Na 26515 członkiń 17722 osoby mieszkały w miastach, 8793 zaś na wsi. Najwięcej, bo 14543, było gospodyń domowych, a robotnic - 11972. Spośród tych ostatnich w kibucach pracowało tylko 2443 - zob.: Czem się trudnią kobiety w Palestynie?, „Przegląd Palestyński” (30 czerwca 1935), nr 10, s. 8.

32 Lilach Rosenberg-Friedman, Kibbutz Ha-Dati Movement (1929-1948), https://jwa. org/encyclopedia/article/kibbutz-ha-dati-movement-1929-1948 [dostęp: 20 listopada 2017], thum. Anna Landau-Czajka. 
publikowano zatem także teksty o artystkach i inteligentkach, wybitnych kobietach zajmujących się sztuką, nauką. Specjalna wysłanniczka „Ewy” w Palestynie opisywała różnorodne zajęcia tamtejszych kobiet, czytelnicy poznawali więc np. solistkę opery palestyńskiej ${ }^{33}$ czy założycielki szkoły dla dziewcząt i szkoły muzycznej ${ }^{34}$. Podkreślano jednak zawsze zaangażowanie kobiet w pracę dla Palestyny, heroizm (np. śpiewaczka występowała nawet po wypadku, bo nie chciała narażać opery na straty finansowe). O ile jednak ukazywanie postaci, które odniosły sukces, wpisywało się w szerszy nurt przedstawiania przez „Ewę" karier zawodowych kobiet, o tyle bardziej interesujące z punktu widzenia tego tematu było pokazywanie życia kobiet palestyńskich mieszkających w miastach, zajmujących się zawodami niezwiązanymi z pracą na roli, w dodatku często bardzo zwyczajnymi. W numerze z kwietnia 1929 r. znajdujemy więc reportaż z telawiwskiej szkoły kroju i szycia przeznaczonej tylko dla kobiet. Oczywiście i te kobiety w przyszłości miały dzięki uzyskanym kwalifikacjom stać się potrzebne ojczyźnie, co bardzo podkreślano, ale na pewno ich umiejętności nie zawsze były - oględnie mówiąc - niezbędne:

Już w najbliższych dniach uruchomiony zostanie w szkole nowy dział - haftu jemenickiego i jeżeli nasze kobiety palestyńskie [...], w dalszym ciągu przejawiać będą tyle energii i zapału, jaki czują dla pracy konstruktywnej w naszym kraju, dzieło ich zapewne trwać będzie przez lata, osiągając rozwój coraz większy! ${ }^{35}$

Ale chyba najważniejszym i najbardziej podważającym wizję kobiet dzielnych chalucek w Palestynie - było jedno zdanie z tego artykułu: „Otrzymane świadectwa [...], są dla nich kluczem zarobku i utrzymania. Nie będą potrzebowały już tłoczyć się w biurze pośrednictwa pracy i ubiegać się o jedną z nadarzających się robót publicznych, o łupanie kamieni”36. Innymi słowy, to, co inne pisma przedstawiały jako wielki sukces i zdobycz kobiet palestyńskich - możliwość wykonywania ciężkiej pracy fizycznej - tu jawi się jako coś, przed czym należy kobiety chronić.

W tekstach „Ewy” wypowiadały się kobiety nieobecne w innych narracjach - te, które wprawdzie wyemigrowały do Palestyny, ale nie zamierzały całkowicie zmieniać życia, pozostały przy dawnych zajęciach i zawodach.

${ }_{33}$ Mirjam Wolman-Sieraczkowa, Solistka opery palestyńskiej (kilka słów o zmartej Lei Golinkin), „Ewa” (1 stycznia 1930), nr 51, s. 3.

${ }_{34}$ Mirjam Wolman-Sieraczkowa, Szkoły w Palestynie, „Ewa” (8 kwietnia 1928), s. 3.

${ }_{35}$ Mirjam Wolman-Sieraczkowa, Szkoła kroju i szycia w Tel Awiwie, „Ewa” (6 stycznia 1929), s. 3.

${ }^{36}$ Tamże. 
Otrzymujemy zupełnie inny obraz życia w Erec - zaskakujący także dla współczesnych czytelników pism syjonistycznych, wychowanych na micie twardych i pracowitych chalucek. Okazywało się, że i w Palestynie można prowadzić mało heroiczne, lecz za to dosyć przyjemne życie. „Ewa” zdawała sobie przy tym sprawę, że burzy mit:

Najmniej chyba wiedzą czytelniczki o naszym życiu towarzyskim w Palestynie mam na myśli życie tych ludzi, którzy wprawdzie wyemigrowali do Palestyny, lecz nie zmienili swej formy życiowej i pozostali przy swych zawodach. Dokądkolwiek przyjeżdżam i spotkam mych dawnych znajomych - wszędzie litują się nade mną, wyobrażając sobie, jak to tam „nudno” musi być w tej Palestynie, jak my tam żyjemy bez tych wszystkich przyjemności wielkich miast, bez jazzu, dancingu i bodaj bez flirtu. Otóż przede wszystkim dla uspokojenia mogę dodać: Jest jazz i ludzie tańczą, i młodzież się bawi, jak wszędzie, bo to prawo życia. [...] Mamy teatry, koncerty, odczyty uniwersyteckie, odczyty towarzystw archeologicznych, wystawy obrazów, wystawy kwiatowe, wystawy ogólne, bale, rauty, fivy, przyjęcia w Government House, recepcje na cześć przyjeżdżających gości, karnawał purymowy w Tel Awiwie, sporty, wyścigi. Mój Boże - za wiele tego wszystkiego ${ }^{37}$.

Jednak i w „Ewie” znajdowały się reportaże podkreślające wyższość pracy fizycznej i pokazujące, że nawet wykształcone kobiety, które jadą do Erec, nie wstydzą się zostawać robotnicami. W rozmowie z Adą Fiszman, przywódczynią robotnic w Palestynie, pada stwierdzenie, że robotnice palestyńskie nie wywodzą się z „naturalnego elementu robotniczego": „Nasze robotnice, to nieraz córki finansistów, zamożnych kupców, których rodzice i teraz częstokroć prowadzą życie wystawne i strofują w listach córeczki, błagając, by powróciły pod rodzinną strzechę i korzystały z wygód i dobrobytu"38. Córki oczywiście nie wracają - nie tylko dlatego, że są ideologicznymi syjonistkami i chcą poświęcić życie pracy nad rozwojem Erec, ale także dlatego, że tylko Palestyna daje kobietom prawdziwą wolność: „Jedynym miejscem wyzwolenia kobiety żydowskiej jest Palestyna. Kobieta uczestniczy tu wszak na równi z chalucem w dziele odbudowy ojczyzny, jak on pracując w polu, w ogrodzie, w fabryce itd." ${ }^{39}$

W rzeczywistości sprawa równouprawnienia kobiet wcale nie była oczywista. W 1925 r. ogłoszono w Palestynie plebiscyt - z udziałem kobiet w którym miano zadecydować o prawie kobiet do głosowania do Asefat

${ }^{37}$ Zofia Sokołów-Raczkowska, Jak żyjemy w Palestynie?, „Ewa” (1 grudnia 1929), nr 48, s. 2.

${ }^{38}$ Wolman-Sieraczkowa, Robotnica żydowska..., s. 2.

39 Tamże. 
ha-Niwcharim ${ }^{40}$. „Nasz Przegląd” wszedł w ostry spór z Agudą ${ }^{41}$, odmawiającą kobietom praw wyborczych. Z prawdziwą odrazą pisano o staraniach Agudy, by chalucki pozbawić w Palestynie prawa głosu. Oburzony publicysta stwierdzał, że Aguda w ten sposób wypowiada walkę tym, którzy własnymi rękami budują przyszłość żydowską w Palestynie, czyli przyszłości narodu żydowskiego ${ }^{42}$.

W 1939 r. pojawiają się w prasie polskojęzycznej - i to przeznaczonej dla młodzieży - artykuły, z których jednoznacznie wynika, że dziewczęta w Erec są dyskryminowane. W reportażu z kibucu położonego nieopodal Hajfy autorka skarżyła się, że przez półtora roku dziewczyny zajmowały się wyłącznie najprostszą pracą w gospodarstwie i w dodatku praktycznie nie miały możliwości opuszczenia terenu. Dopiero dzięki wybudowaniu własnego domu dziewczęta znalazły rozsądne i pożyteczne zajęcia, zaczęto pracować w kuchni czy ogrodzie na zmianę - kobiety i mężczyźni, choć Arabowie - przyjaźnie zatrzymujący się, aby pogadać z kibucnikami - dziwili się, że kobiety wykonują typowo męskie prace. Wtedy też nareszcie zaczęła się - oprócz pracy - m.in. wspólna nauka literatury hebrajskiej, geografii gospodarczej, języka arabskiego, dramatu europejskiego ${ }^{43}$. Innymi słowy, w idealnej Palestynie młode chalucki były dyskryminowane i zaczęły mieć tego dość.

\section{Kobiety i mężczyźni}

I jeszcze jeden problem, uznany za marginesowy i całkowicie pomijany w ideologii, a jak się wydaje, bardzo poważny w realnym życiu - mianowicie kontakty damsko-męskie. Zazwyczaj bardzo młodzi ludzie, wyrwani ze swoich rodzinnych, często zachowawczych domów, przestrzegających tradycyjnego podziału ról, zostali pozostawieni samym sobie w nowym kraju. Stara, tradycyjna ideologia separacji płci mieszała się z nową ideą równości płci. W rezultacie wszyscy byli chyba trochę zagubieni. W dodatku kobiet w Palestynie było zdecydowanie za mało, o czym też raczej nie

${ }^{40}$ Rodzaj parlamentu społeczności żydowskiej w Brytyjskim Mandacie Palestyny, powołanego 19 kwietnia $1920 \mathrm{r}$.

41 Aguda, właśc. Agudas Israel, żydowska, konserwatywna i ortodoksyjna partia polityczna, istniejąca od $1912 \mathrm{r}$. Miała swoich przedstawicieli w parlamencie II RP.

${ }^{42}$ I. Deutsch, $O$ walkę z klerykalizmem żydowskim, „Nasz Przegląd” (14 stycznia 1926), nr 14, s. 4.

${ }^{43}$ Grupa młodzieży „Ahawar”, Hajfa. Praca w troskach i radości. Reportaż palestyński, „Dzienniczek dla Dzieci i Młodzieży” (3 lutego 1939), nr 34, s. 9-10. 
wspominano, żeby - być może - nie zniechęcać młodych mężczyzn do wyjazdu. Rzeczywistość, jaką zastawano na miejscu, różniła się zatem od oczekiwanej, choć trudno znaleźć artykuły opisujące ten problem. Reporter „Małego Przeglądu”, wspomniany Harry, mający zwyczaj pisać wprost i nieobawiający się publikowania niepopularnych opinii, stwierdził w jednym ze swoich palestyńskich reportaży, że z powodu braku dziewcząt i kobiet trudno znaleźć narzeczoną, ale za to każda dziewczyna, nawet bez posagu, znajdzie męża. Pojawia się tu istotna trudność, o której pisano niewiele: problem małżeństw. „Przegląd Palestyński” pisał z oburzeniem, że oskarżenia, jakoby w Palestynie kwitła plaga fikcyjnych małżeństw, są wyssane z palca (chodziło tu o walkę z biurokratycznymi przepisami cechującymi się podejrzliwością wobec młodych małżeństw i utrudniającymi małżonkom wjazd do Palestyny). Po prostu tam, gdzie stale przebywa ze sobą młodzież obojga płci, szybko dochodzi do łączenia się w pary, zawierania związków. A i tak większość mężczyzn, np. z Niemiec, przybywa do Palestyny z żonami (to zresztą bardzo charakterystyczne zdanie, z którego wynikało, że zawsze żona jest dodatkiem do wyjeżdżającego do Palestyny mężczyzny, nigdy zaś odwrotnie). Owszem, nadużycia się zdarzały - stwierdzał autor artykułu - ale rzadko. Trudno jednak wierzyć autorowi artykułu, który jednocześnie przekonuje, że większość chaluców miało żony, a następnie, iż „,najczęściej dopiero wyjazd do Palestyny stwarza warunki, umożliwiające młodym ludziom pobranie się. Bo i kiedyż mogłoby to nastąpić w warunkach naszej chalucowej zaprawy?" ${ }^{44}$ I dodaje, że samodzielne życie i małżeństwo w dziewięciu przypadkach na dziesięć może nastąpić dopiero w Palestynie. Niezależnie od tego, w jakich celach pisany był artykuł, wynikało z niego, że małżeństwa w Palestynie zawierane są bardzo szybko, a dziewczęta rzeczywiście mogą liczyć na znalezienie partnera.

Wspólne przebywanie oraz praca dziewcząt i chłopców budziły czasem wątpliwości nawet wśród ideowych chaluców. Z jednej strony dziewczęta cieszyło równouprawnienie, $\mathrm{z}$ drugiej - obawiały się, że to odziera życie z romantyczności. Pochodząca z Niemiec młoda uczennica szkoły kibucowej pisała:

Koedukacja i wspólne życie chłopców i dziewcząt sprawia, że pewne napięcie erotyczne, które się tworzy między nimi, przeistacza się w czynnik twórczy. Oto jedna z najdroższych naszych wartości. [...] Ale brak nam czegoś... Brak wysubtelnienia w życiu codziennym, wysubtelnienia stosunków wzajemnych między chłopca-

${ }^{44}$ M.H., Fikcyjne matżeństwa i nieżyciowe zarządzenia, „Przegląd Palestyński” (23 czerwca 1935), s. 1-2. 
mi a dziewczętami. To musimy stworzyć. Wydaje mi się, że jednym z środków do osiągnięcia tego celu, może najważniejszym - jest dystans. [...] Po dziś dzień nie znaliśmy go. W mieście to łatwa sprawa. [...] U nas jest inaczej. My żyjemy razem, mamy możliwość podzielenia się przeżyciami najosobistszymi, najbliższymi. [...] Wiemy, jak ocenić, osądzić, usprawiedliwić, obwinić. Bez różnicy wszyscy: malcy i dziewczynki, chłopcy i dziewczęta. Ale brak czegoś w naszych stosunkach. Czegoś subtelnego, niewypowiedzianego, czegoś, co by im dało ostateczny koloryt [...]. Brak nam dystansu, terenu neutralnego między chłopcami a dziewczętami. Tego, co stwarza wzajemne wyczekiwanie siebie, co otacza stosunki nasze niecodziennością, zapachem święta czekanego z zapartym tchem ${ }^{45}$.

Ciekawy jest niemal całkowity brak jednej, niezwykle istotnej narracji - tzn. opisu zjawiska faktycznego w kibucach odsunięcia kobiet od bycia matkami (i mężczyzn od bycia ojcami, ale tekst dotyczy kobiet). Czasami w artykułach pojawiały się wzmianki o tym, że dzieci wychowuje się wspólnie, że nie śpią w domu z rodzicami, lecz w specjalnych domach przeznaczonych dla dzieci, że wychowują je nauczyciele, a nie rodzice, i że w ciągu dnia widzą się z rodzicami tylko parę godzin - albo i mniej. Jak wspominał Aleksander Lewin:

W pierwszym okresie [...] dominowała i obowiązywała uproszczona, nieco sztuczna, uniformistyczna koncepcja wychowania kolektywnego: dzieci są wychowywane wspólnie, jednakowo, kobiety uwolnione od obowiązków domowych i opiekuńczych mogą wykonywać wszystkie zawody, dokonuje się pełna emancypacja. Tego rodzaju koncepcja i praktyka [...] wynikała - jak sądzę - nie tylko z ówczesnej ideologii kibucowej, ale była również narzucona czy wymuszona przez niesłychanie ciężkie, prymitywne warunki życia, kiedy po prostu nie starczało sił i środków, by każdy mógł zająć się swoim dzieckiem i poświęcić mu dostatecznie wiele czasu ${ }^{46}$.

Jeśli taki motyw się pojawiał, to zawsze ze strony dzieci - ich zabaw, nauki, pracy dla kibucu, koleżeństwa, nigdy zaś z punktu widzenia matek pozbawionych możliwości swobodnego wychowywania własnego dziecka. Istotnie, w artykułach podkreślano czasem, że jadalnie i pralnie są wspólne, kobiety nie muszą więc prowadzić gospodarstwa, jednak fakt, iż zostały też zwolnione z opieki nad własnymi córkami i synami, starano się dyskretnie pomijać. Wprawdzie, jak twierdzi Aleksander Lewin, wspólne wychowanie dzieci było jednym z elementów dążenia do równouprawnienia, ale chyba jednak nie takiego, jakiego życzyłyby sobie myślące o wyjeździe chalucki. Prawdopodobnie taka wizja nie zachęciłaby dziewcząt do wyjazdu.

${ }^{45}$ Ruth, Dziewczęta i chtopcy ( problematyki szkoły w Miszmar-Haemek), „Młody Czyn” (marzec 1938), nr 2, s. 5.

46 Aleksander Lewin, Kibuce w Izraelu. Utopia czy rzeczywistość, Warszawa 1992, s. 61-62. 


\section{Podsumowanie}

Podsumowując, trzeba stwierdzić, że prasa syjonistyczna koncentrowała się na pokazywaniu wyidealizowanego obrazu życia kobiet w Palestynie. Dominował w niej więc wizerunek kobiety chalucki ofiarnie, na równi z mężczyznami pracującej na roli, oddanej przede wszystkim działalności dla Erec. Podkreślano równość płci i sukcesy kobiet palestyńskich zarówno tych pracujących fizycznie, jak i tych z miast. Jeśli opisywano problemy, to nie w kontekście specyficznych trudności dotykających kobiety w Erec, ale raczej jako dolegliwości wszystkich żydowskich mieszkańców Palestyny. Starano się też omijać temat zakładanych w kibucach rodzin, prawdopodobnie nie chcąc zniechęcać potencjalnych imigrantek wizją nietypowego macierzyństwa - dzieci wychowywanych wspólnie. Innymi słowy, dziewczęta wyjeżdżały, mając przed oczami nie to, co rzeczywiście je w Palestynie czekało. Czy zatem wracały? Oficjalnie nie. Nieoficjalnie - sporo osób po pewnym czasie wracało, nie tylko zresztą dziewczęta. Ale to akurat było jednym z największych tabu prasy syjonistycznej.

\section{Bibliografia}

\section{1. Źródła opublikowane}

„Diwrej Akiba” 1936.

„Dzienniczek dla Dzieci i Młodzieży” (dodatek do „Nowego Dziennika”) 19251939.

„Ewa” 1928-1930.

„Filary. Miesięcznik Akademicki” 1939.

„Mały Przegląd” (Dodatek dla dzieci i młodzieży do „Naszego Przeglądu”) 1926-1939.

„Młody Czyn. Pismo Młodzieży Szomrowej” 1938.

„Nasz Przegląd” 1923-1939.

„Nasze Hasła” 1928.

„Nowe Tory. Organ Polskiej Federacji W.I.Z.O.” 1935-1936.

„Przegląd Palestyński” 1935.

„Tygodnik Żydowski” 1919-1920.

\section{Opracowania}

Czerwonogóra Katarzyna, Syjonistyczny ruch kobiet w Europie na przełomie XIX i XX wieku, „Studia Judaica” 18 (2015), nr 2.

Lewin Aleksander, Kibuce w Izraelu. Utopia czy rzeczywistość, Warszawa 1992. 
Rosenberg-Friedman Lilach, Kibbutz Ha-Dati Movement (1929-1948), https:// jwa.org/encyclopedia/article/kibbutz-ha-dati-movement-1929-1948 [dostęp: 20 listopada 2017].

Szabłowska-Zaremba Monika, „Okienko na Świat. Pismo dzieci i młodzieży” 1937-1939, „Annales Universitatis Paedagogicae Cracoviensis. Studia ad Bibliothecarum Scientiam Pertinentia" 13 (2015).

Tiger Lionel, Shepher Joseph, Women in the Kibbutz, New York-London 1975.

Anna Landau-Czajka

IH PAN

alandau@op.pl 